\title{
USE OF SOCIAL MEDIA FOR HEALTH EDUCATION AND CORPORATE COMMUNICATION OF HOSPITALS
}

\section{Uso de redes sociales para la educación en salud y la comunicación corporativa de hospitales}

Carmen Costa-Sánchez and María-Isabel Míguez-González

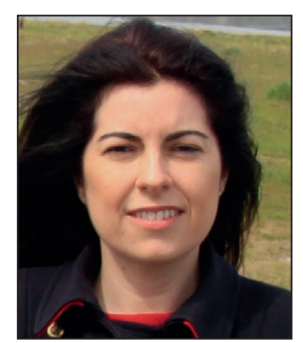

Carmen Costa-Sánchez is an associate professor of Corporate Communication in Audiovisual Communication (Universidade da Coruña) and holds her PhD in Communication from the Universidade de Santiago de Compostela (USC). Professor Costa-Sánchez was awarded an extraordinary doctorate by the Faculty of Communication Sciences of USC. Her main lines of research are Corporate communication, Health communication, and Mobile communication. She is co-editor of the books Comunicación corporativa. Claves y escenarios (Barcelona: UOC), and Comunicación corporativa audiovisual y online. Innovación y tendencias (Barcelona: UOC).

https://orcid.org/0000-0001-8154-9537
Universidade da Coruña Facultade de Ciencias da Comunicación Departamento de Socioloxía e Ciencias da Comunicación Campus de Elviña, s/n. 15071 A Coruña, Spain

carmen.costa@udc.es

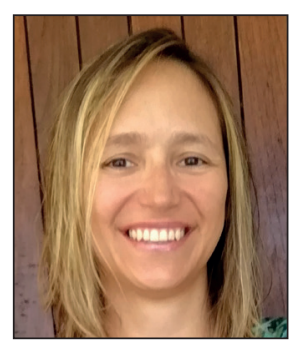

María-Isabel Míguez-González is an associate professor in the Faculty of Social Science and Communication (Universidade de Vigo), where she teaches Theory and Practice of Public Relations and Communication Management in Advertising and Public Relations. She coordinates the research group on communication for public service (Sepcom); her main lines of research are Health communication, Public relations, Communication management, and Online communication for tourism. https://orcid.org/0000-0002-0580-8493
Universidade de Vigo Facultade de Ciencias Sociais e da Comunicación Departamento de Comunicación Audiovisual e Publicidade Campus A Xunqueira, s/n. 36005 Pontevedra, Spain mabelm@uvigo.es

\begin{abstract}
The main objective of this work is to obtain an in-depth understanding of digital communication strategies employed by hospitals by comparing and contrasting the digital communication of two hospitals of reference in Spain. The main method is content analysis of Facebook and Twitter along with in-depth interviews of hospital communication directors. Results show different communication strategies that depend on organizational goals. The public participated in digital communication within three themes: 1) general, sensitive, and topical health issues; 2) personal and professional projects, as well as initiatives for struggle or sensitization; 3) corporate novelties that encourage public involvement. The use of currently existing platforms of social media from which to manage the online communication should be a priority for hospitals. Multimedia content can help to disclose health information. Online communication strategies are adapted to overall communication strategy and differences in cultural profiles lead to differences in priorities.
\end{abstract}

\section{Keywords}

Communication strategies; Public relations; Health communication; Corporate communication; Social media.

\section{Resumen}

El objetivo principal de este trabajo es obtener un conocimiento profundo de la comunicación de dos hospitales españoles de referencia en comunicación digital, contrastando sus estrategias. Los principales métodos utilizados son el análisis de contenido de Facebook y Twitter y entrevistas en profundidad con los directores de comunicación de ambos hospitales. Los resultados muestran diferentes estrategias de comunicación sujetas a los objetivos de cada organización. La participación del público se produce en tres tipos de temas: 1) cuestiones de salud de interés general, especialmente sensibles; 2) proyectos personales y profesionales reconocidos, así como iniciativas para la lucha o la sensibilización; 3) novedades corporativas relevantes que afectan a la organización y fomentan la participación de su red. La existencia 
de una o más plataformas de redes sociales desde las cuales administrar la comunicación online es una prioridad para los hospitales. Los contenidos infográficos pueden ayudar a educar en salud. Las estrategias de comunicación online se adaptan a la estrategia general de comunicación y las diferencias en los perfiles culturales llevan a diferencias en sus prioridades estratégicas.

\section{Palabras clave}

Estrategias de comunicación; Relaciones públicas; Comunicación para la salud; Comunicación corporativa; Medios sociales.

Costa-Sánchez, Carmen; Míguez-González, María-Isabel (2018). “Use of social media for health education and corporate communication of hospitals". El profesional de la información, v. 27, n. 5, pp. 1145-1154.

https://doi.org/10.3145/epi.2018.sep.18

\section{Introduction}

As social media tools become mainstream, organizations must update their strategies and tactics to build relationships (Briones et al., 2011). In line with other types of organizations, social media are new channels for hospitals to communicate with citizens and users. Online dialogue can be an important method of health education, an unusual topic in the current communication research agenda (Vande-Belt et al., 2012; Thackeray et al., 2012; Moorhead et al., 2013).

This work aims to help fill this gap and deepen the use of the two social networks with the most users in Spain, Facebook and Twitter, by two Spanish hospitals with very different identities, but both with a reputation in Spain for their services and also activities in the digital arena. The Hospital Sant Joan de Déu, (HSJD) in Barcelona, a maternal and children's hospital of concerted management with the Catalan Public Health Service and the Clínica Universidad de Navarra $(C U N)$, a general hospital of private ownership and management.

\section{Literature review}

Although there are many potential benefits of adopting social media for medical practices and health care (Lim, 2016), and despite users who are becoming more and more informed on health topics thanks to the Internet (Sarasohn-Kahn, 2008; Hu; Sundar, 2010), health care organizations are latecomers to the digital arena. Also, much remains to be done to educate, give answers, and open more direct communication paths with users (Gabarrón; Fernández-Luque, 2012; Huerta et al., 2014).

In regards to the use of social media, according Van-de-Belt et al. (2012), the number of hospitals in western European countries that use such tools is minimal. In Italy less than 8 percent of public hospitals and local health authorities have social media accounts (Vanzetta et al., 2014). In US hospitals the largest private non-profit and urban hospitals are those with higher social media activity (Griffis et al., 2014; Richter; Muhlestein; Wilks, 2014) and 42 percent of the analyzed Canadian hospitals have no Facebook profile (Medina-Aguerrebere; Buil-Gazol; Heath, 2015). In Farabough's (2013) approach, the posts that generated greater engagement were those related to patient stories. Pictures, videos, and good news tended to increase usage of social media for hospital stakeholders (Leung, 2014).
One current weakness in social media management by public health agencies is a lack of interactivity and engagement with the user (Thackeray et al., 2012). Additionally, the number of Facebook likes works as an indicator of hospital quality and patient satisfaction (Timian et al., 2013). McCaughey et al. (2014) detected a positive correlation between social media channel use and patient rating of their overall hospital experience, as well as patient willingness to recommend the hospital.

\section{Both hospitals have one or more webs/ blogs that feed the content they re-dis- seminate through Twitter and Facebook}

In Spain a significant percentage of hospitals do not have a website, and those that do are not optimizing them as a medium of information that is of interest to their publics, according to the results of several studies (Arencibia-Jiménez; Aibar-Remón, 2007; Díaz-Cuenca, 2007; Calvo-Calvo, 2014). Bermúdez-Tamayo et al. (2013) show that, in Spain, the larger institutions use social networks more frequently, as well as public institutions $(19 \%, \mathrm{p}<0.01)$ compared to private ones. But half of the Spanish hospitals with better reputation are not yet present in social media (Costa-Sánchez; Túñez-López; Videla-Rodríguez, 2016). The presence of Spanish hospitals on social media is evolving, but it is very low compared to hospitals in the United States and other western European countries. Spanish public hospitals are more active on Twitter, whereas private hospitals have a better performance on Facebook and YouTube (Martínez-Millana et al., 2017). In an analysis of Twitter management by Spanish hospitals (Rando-Cueto; Paniagua-Rojano; De-lasHeras-Pedrosa, 2016), users are interested in information about the activity and events of the hospital followed by practical information and health advice.

The main objective of this work is to gain an in-depth understanding of the use of the social networks, Facebook and Twitter, by two hospitals in Spain and to contrast the communication strategies of the chosen hospitals. Most of the previous research has analyzed the overall situation, but has not explored communication strategies, objectives, and resources. The analysis will allow us to extract lessons that can be applied to the hospital sector, which in Spain have been late to social media use, just reacting to the new communicative context. 


\section{Method}

The two hospitals (HSJD and CUN) were chosen because of the contrasts in their management (public-private) and specialization (maternal and child-general). Both are academic hospitals. Each has a website, presence in social networks (Facebook, Twitter and YouTube, among others), and blogs. This is an extensive presence in 2.0 platforms, which are listed in the corresponding sections of the web pages of HSJD and CUN.

https://www.sjdhospitalbarcelona.org/es/siguenos-redessociales

https://www.cun.es/actualidad

Previous studies have identified Sant Joan de Dèu Hospital in Barcelona and Clínica Universidad de Navarra as the two most active Spanish hospitals in social media (Costa-Sánchez; Túñez-López; Videla-Rodríguez, 2016). The combination of this group of factors justifies using these two hospitals in our study. Facebook and Twitter are the object of study because they are the two most popular social networks in Spain (IAB Spain, 2016).

In order to carry out an in-depth analysis of the online activity of the two hospitals and a comparative study between both, the present work poses the following initial questions:

R.Q.1. What level of activity do the hospitals present in both social networks?

R.Q.1.1. Are there any significant differences in this regard?

R.Q.2. What is the followed priority strategic line for the content published on Facebook and Twitter?

R.Q.2.1. Are there differences detected between the two organizations?

R.Q.3. What content generates more conversation in social networks?

Table 1. Data analysis tool

\begin{tabular}{|c|c|c|}
\hline Item & \multicolumn{2}{|c|}{ Indicators } \\
\hline \multirow{3}{*}{ General activity index } & Tweets/ day & Tweets/month \\
\hline & Posts/day & Posts/ month \\
\hline & Total tweets & Total posts \\
\hline \multirow{4}{*}{ Priority issue } & \multicolumn{2}{|c|}{ Informational } \\
\hline & \multicolumn{2}{|l|}{ Corporate } \\
\hline & \multicolumn{2}{|l|}{ Scientific } \\
\hline & \multicolumn{2}{|l|}{ Other } \\
\hline Title (/unit) & \multicolumn{2}{|c|}{ Free coding and decoding } \\
\hline \multirow{5}{*}{ Multimedia index } & \multicolumn{2}{|l|}{ Picture } \\
\hline & \multicolumn{2}{|l|}{ Video } \\
\hline & \multicolumn{2}{|l|}{ Audio } \\
\hline & \multicolumn{2}{|c|}{ Computer graphic } \\
\hline & \multicolumn{2}{|l|}{ Other } \\
\hline Origin of information & \multicolumn{2}{|c|}{ Free coding and decoding } \\
\hline \multirow{4}{*}{ Conversation index } & Retweets & Likes \\
\hline & \multirow{3}{*}{ Loves } & Interactions \\
\hline & & Shares \\
\hline & & Comments \\
\hline
\end{tabular}

\section{R.Q.3.1. Are there any coincidences in this regard?}

R.Q.4. What is the online communication strategy that both hospitals are currently implementing?

Thereafter, a content analysis adapted to the possibilities of the channel covering a period of three months was carried out for both organizations: February, April, and June 2016 for Hospital Sant Joan de Déu; and September, November, and January 2017 for CUN. Alternate months were selected to avoid possible distortions derived from specific events and to observe the communication strategy in a global time arch of six months in each case.

\section{Clínica Universidad de Navarra's inno- vative commitment to careful computer graphics that summarize and explain health information at a glance is highli- ghted}

Starting from Griffis et al. (2014); Richter, Muhlestein \& Wilks (2014); King (2014); Saxton \& Waters (2014) and Kordzadeh \& Young (2014), a factsheet was created for each social network, taking into account the following elements (see Table 1).

The categories of the issues come from the synthesis of previous studies (Wong et al., 2016, Rando-Cueto; Paniagua-Rojano; De-las-Heras-Pedrosa, 2016; Kordazeh; Young, 2015, Huang; Dunbar, 2013; Xifra; Grau, 2010). For this purpose, all the content related to institutional communication and public relations has been considered as corporate content. Informational content refers to content that covers topics of communication for health. Scientific topics are those related to research and clinical trials, fundamentally. This simplification effort aims to facilitate the comparison between different entities.

Several of these variables have been interrelated in the descriptive section of the corresponding results. The measures for the content with greater interaction from users were relative according to the means of each organization for each social network (King, 2014).

Then, semi-structured, online interviews with the communication directors from each hospital were used to obtain an in-depth understanding of the view of the people in charge of the communication strategies conducted by hospitals. Both communication directors participated in the study. The explanations given by the heads of both departments are included in the different topics covered.

The combination of the quantitative and qualitative methodology allows us to complement the message analysis (strategy, content, and channels) with the recognized and verbalized intentionality by those responsible for the strategy design (Sale; Lohfeld; Brazil, 2002). 
Table 2. General data of corporate websites

\begin{tabular}{|l|l|c|c|c|c|}
\hline \multicolumn{1}{|c|}{ Web } & \multicolumn{1}{|c|}{ URL } & Global rank & $\begin{array}{c}\text { Spanish } \\
\text { rank }\end{array}$ & Bounce rank & Pages \\
\hline CUN & http://www.cun.es & 51,012 & 4,290 & $85.40 \%$ \\
\hline HSJD & https://www.sjdhospitalbarcelona.org/es & 497,063 & 26,580 & $45.20 \%$ \\
\hline Faros HSJD & http://faros.hsjdbcn.org & 357,599 & 19,876 & 2.80 \\
\hline
\end{tabular}

Source: Alexa.com

\section{Results}

\subsection{Activity on the web}

In terms of traffic data from corporate websites, the data obtained from Alexa, one of the most used web references for media planning, are included. The specific items shown are:

- global position in the ranking of websites.

- position in Spanish ranking.

- number of pages visited.

- average duration of visits.

- bounce rank or number of visits that only access a page and leave the site.

As it may be appreciated, the CUN website is the best positioned in the global and Spanish ranking, although its bounce rate is the highest and the average visit time is the lowest of the three. It is important to emphasize that Faros, the online portal specializing in health that belongs to HSJD, has a better positioning than the corporate website of the hospital, although the latter seems to be of greater interest for the public, when we take into account the time of the visit, the pages visited, and the bounce rate (see Table 2 ).

\subsection{Activity index on Facebook/ Twitter}

Comparatively, as indicated by monthly average activity on networks during the analyzed period (see Table 3), the CUN has double the social media activity of HSJD, being much more up-to-date in the microblogging network when compared to the hospital's Facebook account (R.Q.1). The CUN's daily average of content publication is double that of HSJD in both networks (R.Q.1.1).

Table 3. Comparative activity index

\begin{tabular}{|l|l|c|c|}
\cline { 2 - 4 } \multicolumn{2}{c|}{} & HSJD & CUN \\
\hline \multirow{4}{*}{ Twitter $(u)$} & Tweets & 7,586 & $13 \mathrm{~K}$ \\
\cline { 2 - 4 } & Following & 319 & 731 \\
\cline { 2 - 4 } & Followers & $13,4 \mathrm{~K}$ & 9,531 \\
\cline { 2 - 4 } & Average tweets/ month & 65.6 & 144 \\
\cline { 2 - 4 } & Average tweets/ day & 2.2 & 4.75 \\
\hline \multirow{3}{*}{ Facebook $(u)$} & Fans & 100,454 & 19,348 \\
\cline { 2 - 4 } & Average posts/ month & 26.3 & 58.6 \\
\cline { 2 - 4 } & Average posts/ day & 0.9 & 1.9 \\
\hline
\end{tabular}

\subsection{Purpose of the use of social networks and the degree of multimedia}

Communication content for health is more prevalent in the networks belonging to the HSJD, both in Facebook and Twitter.

In CUN's case, the corporate use in Twitter is almost equal to its use in communicating about health, whereas Facebook is a network that is used more for health (Table 4). Scientific content is transmitted by Twitter in the case of HSJD, but it is absent from their Facebook channel, while CUN makes limited use in both networks for this purpose (R.Q.2, R.Q.2.1).

A commitment to images in Twitter and Facebook is a common denominator in the channels of both organizations (Table 5). Emphasis is given to the use of self-made explanatory infographics designed to help better understand complex information. In addition, CUN makes greater use of video. The fact of having a multimedia area in the working environment at the hospitals dedicated to the creation of these materials is reflected, therefore, in the format of the shared content.

\subsection{Impact on networks}

The conversation rate is higher on Twitter for CUN and Facebook for HSJD (Table 6). In the average by type of content,

Table 4. Compared types of use

\begin{tabular}{|c|c|c|c|}
\hline \multicolumn{4}{|c|}{ Type of use (\%) } \\
\hline & & HSJD & CUN \\
\hline \multirow{4}{*}{ Twitter } & Informational/ educational & 51.8 & 38.8 \\
\hline & Scientific & 24.3 & 11.5 \\
\hline & Corporate & 16.7 & 36.2 \\
\hline & Other & 7.1 & 13.4 \\
\hline \multirow{4}{*}{ Facebook } & Informational/ educational & 70.8 & 52.6 \\
\hline & Scientific & 0 & 8.6 \\
\hline & Corporate & 20.2 & 29.1 \\
\hline & Other & 8.9 & 9.7 \\
\hline \multirow{4}{*}{ Total } & Informational/ educational & 57.2 & 42.7 \\
\hline & Scientific & 17.4 & 10.7 \\
\hline & Corporate & 17.7 & 34.2 \\
\hline & Other & 7.6 & 12.3 \\
\hline
\end{tabular}


Table 5. Multimedia index

\begin{tabular}{|l|l|c|c|}
\hline \multicolumn{4}{|c|}{ Content format (\%) } \\
\hline \multirow{4}{*}{ Twitter } & Image & HSJD & CUN \\
\cline { 2 - 4 } & Video & 68.5 & 61.9 \\
\cline { 2 - 4 } & Text & 1 & 10.6 \\
\hline \multirow{5}{*}{ Facebook } & Graphics & 30.4 & 15 \\
\cline { 2 - 4 } & Image & 0 & 12.5 \\
\cline { 2 - 4 } & Video & 97.4 & 52 \\
\cline { 2 - 4 } & Text & 1.3 & 26.3 \\
\cline { 2 - 4 } & Graphics & 1.3 & 5.7 \\
\hline
\end{tabular}

the CUN stands out again in Twitter, while the conversation generated by HSJD posts are higher in comments, times shared, and reactions (R.Q.3).

Communication topics for health generated more impact and participation in both Twitter and Facebook for HSJD. In the case of CUN, the topics of corporate profile on Twitter and Facebook are the ones that give rise to greater conversation and user interactions (Table 7, R.Q.3.1).

\subsection{Online communication strategies}

Below is a description of the current online communication strategies used by both hospitals (R.Q.4); the description is based on the work of observation and analysis of networks and platforms and on the intentions as stated by the communication directors of both hospitals.

\subsubsection{Hospital Sant Joan de Déu}

As for the use of Twitter, three priority lines of content stand out:

First, the informational content, where the channel works as a loudspeaker of the content of Faros, the online portal of education for health. The website mainly offers content according to two criteria: age (prenatal, first year, 1 to 5 years, 5 to 12 years, and adolescence) and subject (Nutrition; Health; Safety; Development and Learning; and Family and News).

The communication director explains that "the priority of

Table 7. Impact index by topic - comparison

\begin{tabular}{|l|l|r|r|}
\hline \multicolumn{4}{|c|}{ Topics-impact (\%) } \\
\hline \multirow{2}{*}{$\begin{array}{l}\text { More retweets / } \\
\text { loves (Twitter) }\end{array}$} & Corporate & HSJD & CUN \\
\cline { 2 - 4 } & Informational & 28.8 & 45.6 \\
\cline { 2 - 4 } & Scientific & 48.8 & 29.4 \\
\cline { 2 - 4 } & Other & 4.4 & 13.2 \\
\hline \multirow{3}{*}{$\begin{array}{l}\text { More shared / } \\
\text { reactions (Face- } \\
\text { book) }\end{array}$} & Corporate & 17.7 & 11.7 \\
\cline { 2 - 4 } & Informational & 14.3 & 49.2 \\
\cline { 2 - 4 } & Scientific & 82.1 & 26.2 \\
\cline { 2 - 4 } & Other & 0 & 14.7 \\
\hline
\end{tabular}

Table 6. Conversation rate

\begin{tabular}{|l|l|c|c|}
\hline \multicolumn{4}{|c|}{ Conversation rate (n) } \\
\hline \multirow{3}{*}{ Twitter } & Retweets & HSJD & CUN \\
\cline { 2 - 4 } & Likes & 774 & 3,873 \\
\hline \multirow{3}{*}{ Facebook } & Comments & 718 & 4,286 \\
\cline { 2 - 4 } & Times shared & 799 & 234 \\
\cline { 2 - 4 } Average tweet & Reactions & 15,163 & 10,792 \\
\cline { 2 - 4 } & Retweets & 44,885 & 21,536 \\
\cline { 2 - 4 } & Likes & 3.9 & 8.9 \\
\hline \multirow{3}{*}{ Average post } & Comments & 3.6 & 9.9 \\
\cline { 2 - 4 } & Times shared & 10 & 1.33 \\
\cline { 2 - 4 } & Reactions & 568 & 122.3 \\
\hline
\end{tabular}

our communication is to carry out actions that help position our hospital as a center of reference in quality and excellence in all matters related to children, youth, mothers, and health" (Communication Director, HSJD). Faros represents the online materialization of this objective.

The content chosen for dissemination on Twitter stands out for their up-to-date nature, social interest, and adaptation to context. All of the posts are accompanied by an illustrative image. As a strategy, the opportunity offered by the World Day of different diseases (World Autism Day, World Day of Childhood Cancer, World Health Day dedicated to diabetes) is used to disseminate issues related to prevention or awareness of the disease. Other events (such as St. George's Day) are also used to discuss the importance of reading among children or stationary issues such as allergies or the importance of sun protection. In any case, contextual factors to generate content are taken into account, in order to attract attention and generate interest.

\section{Facebook is employed by Hospital Sant} Joan de Déu as a community channel where parents find articles of interest about their children's health

Scientific content related to maternity, pregnancy, and pediatrics occupy the second place. The content published by the library channel are disseminated. This content are published in English, and is not accompanied by any image. This content has very low impact in terms of retweets.

Third, corporate content is linked to the celebration of days and events, fundraising for research and hospital projects with lines of collaboration with other entities, prizes received or media coverage of hospital activities and interviews to its professionals. The hospital's corporate website and friends are usually the reference sources.

Regarding the main strategies on Facebook, health and weIlness tips are prioritized for parents, children, and adolescents, in tandem with posts on Twitter. The Faros platform also serves as a support to the main strategy on Facebook. 
The strategy of scientific dissemination has disappeared. It is replaced by a near and familiar channel. It also includes user service information, especially that which is related to the internal activities of the hospital.

Facebook acts as a channel for its own community, with a more familiar language, while Twitter is committed to positioning itself as a scientific and research source and, in this sense, more professional, but less close to the user. In essence, Facebook is the channel for the community of parents who find special interest in hospital content.

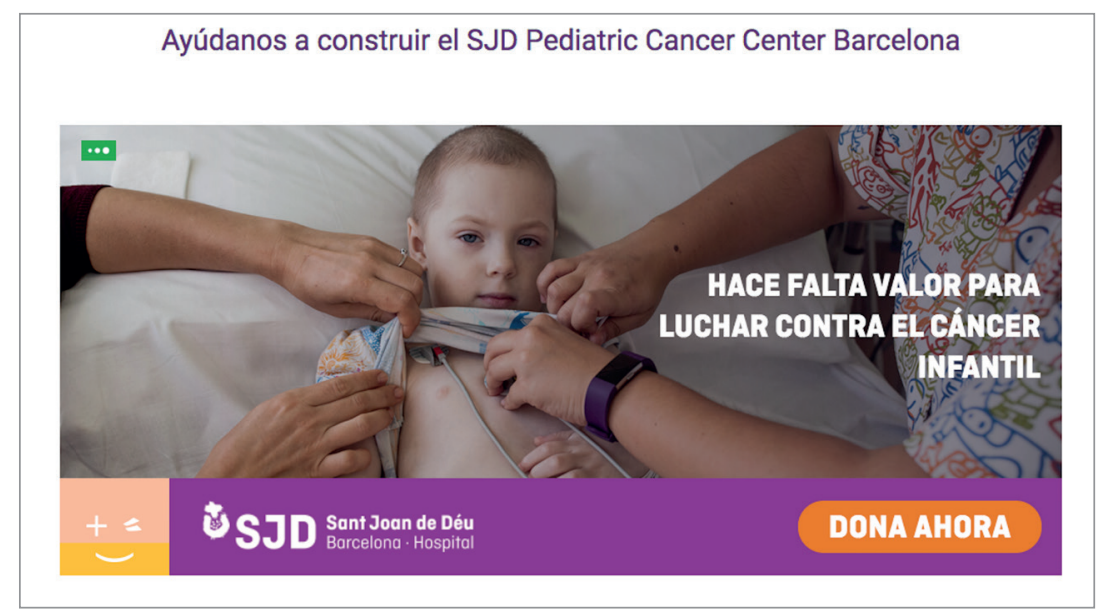

HSJD corporate website

The content that generated the highest level of participation on Twitter was in relation to the World Day against Childhood Cancer (February 15). In descriptive terms, the snapshot of the content with the highest conversation rate was in relation to the dissemination of topics of general social concern, namely: childhood cancer, blood donation, sport benefits, importance of the use of protective cream, and the prevention of children's accidents.

The content linked to specific personal projects generated affinity (loves) because the same network of people supported the corresponding content.

The Facebook/Twitter contrast shows, first, that more activity is not synonymous to more interaction with audiences

Regarding Facebook, dialogue (higher index of comments) arose with sensitive issues (awareness-raising initiatives with a concrete project or the World Day Against Childhood Cancer) and professional projects of success and social impact, as well as certain corporate issues, which are common to health professionals.

With regards the rebroadcast indicator (number of times shared), an explanation of the risks of using mobile devices for the visual health of children (912 times shared), the topic of childhood cancer, and the importance of educating without raising the voice (732 times shared), the role of parents in disease processes (659 times shared), and content on rare diseases (634 times shared) were the topics.

The analysis shows that promotion and prevention on health was the main goal of sharing content in the hospital network, delegating to the second level the more corporate and scientific dimensions. Staff at the hospital understood their social media strategy as a "means of helping families".

\subsubsection{Clínica Universidad de Navarra}

The CUN content strategy on Twitter had several purposes. As was the case of HSJD, health-related content was being disseminated and seasonal and ephemerid moments were used.

Second, but with a much higher presence than the publications dedicated to dissemination, corporate content had a significant share of presence on the channel. In particular, three strategic sub-lines were detected in this sense:

1. The opening of the new clinic in Madrid, scheduled for autumn 2017. In September 2016 (a year earlier), content was already being generated on facilities, professionals, lines of activity, etc. The communication director of the hospitals recognized that "the immediate priority of the Department is to communicate the identity and the brand of the hospital for the project of the new headquarters (...) in Madrid."

2. The relevance of the University of Navarra for the community. The report on the socio-economic impact of the University in Navarre and the presentation of its corporate memory give rise to emphasizing the organization as a focus for promoting resources and the well-being of its environment.

3. The provision of data and information on CUN as a reference entity in quality of service and innovation. Acknowledgments to its professionals, organization of events, balance of services provided, agreements signed with other entities or new facilities.

Associating CUN with a leadership image at the national and international medical-sanitary level was the goal of this line of content.

Third, scientific content brings news about clinical trials carried out, studies and new diagnostic procedures, training activities and conferences of its professionals. This is a line of content that, although it is technical and of interest to a more specialized public, also underlines the image of CUN as a pioneer center in medical treatments, innovation, and excellence.

Twitter content comes mainly from the active blogs of the hospital and the hospital's own website. The corporate website has, besides a link to blogs, a section in the main menu called diseases and treatments. It is the dissemination of health content housed in a key place on the website and at the same level as corporate content. 
As a university clinic, content related to the faculties of Medicine and Nursing and other institutions of the University were also part of a network which was re-distributed. The media as a source of content was a common resource, in many cases related to publications where the center's medical professionals are protagonist.

With regard to content strategy on Facebook, the corporate website and blogs increased their presence as a source of original content. The corporate website increased its presence linked to the health promotion strategy and the extensive section on the web dedicated to diseases and treatments.

\section{The interaction and participation of the public occurs in three types of issues}

The content that generated a greater participation on Twitter (equal or more than 20 retweets and loves) were mainly those related to diseases of great social sensitivity (childhood cancer, Alzheimer's, and premature babies), those linked to the University of Navarra network (organizations integrated into the network of the institution, such as faculties or research institutes), and those concerning news of the Athletic Club Osasuna, a Spanish club of first division located in Pamplona that has an agreement with the hospital to provide medical care for its players.

Regarding the participation of the audience in Facebook, the conversation (equal or more than 60 times shared and 120 reactions) was more active in relation to corporate issues related to the opening of the new hospital in Madrid and its characteristics and the impact of the hospital and university on the Navarra region. Both topics were also featured on Twitter. Informational content that generated greater participation was information related to ailments of broad social concern, such as cancer.

The medium-term goal of a hospital within the new paradigm is to

"take advantage of all the possibilities offered by the 2.0 context to develop a closer and interactive communication among all our audiences" (Communication Directorate, CUN).
As explained by the hospital's communication department, social media helps to consolidate online reputation and is a means to cultivate the community of followers through content generation, the dissemination of identity, and active listening of users.

\section{Discussion and conclusions}

The study shows the existence of one or more base platforms from which to manage the online communication through the social networks of Twitter and Facebook. Both hospitals have one or more webs/blogs that feed the content they re-disseminate through Twitter and Facebook. The corporate website is the main platform for CUN (the fact that blogs are also hosted increases web traffic from social networks to the corporate website). HSJD separates the two strategies into two different platforms: for health communication, it uses Faros (an online portal with specific content for its priority audiences, i.e. teenage/mother/parents), while the corporate website plays a secondary but stable role, limited to the identity information of the organization.

This is also visible in the online communication strategy of both entities. While CUN prioritizes content at the service of corporate communication and even the other lines of content are ultimately dependent on the purpose of corporate communication, HSJD platforms perform a triple role: first, an informative role; second, public relations position; and in the third place, the scientific role. The planning process for the opening of the new headquarters in Madrid is, according to the director of communication, the most immediate priority. In contrast, for the Catalan hospital, becoming a reference in the health area of specific groups (mothers and fathers, fundamentally) means that the vector of communication in health has a greater role, since it will also enable it to reach potential customers at a national and international level.

With regard to CUN's communication strategy, the high degree of implemented planning of communication should be highlighted. It is also an indicator of the importance of the generation of own audiovisual materials (image, computer graphics, or video) to provide content to networks, so the creation of a multimedia department (which in this case, CUN already has) is outlined as a line of work of interest for the communication direction in this and other types of sectors.

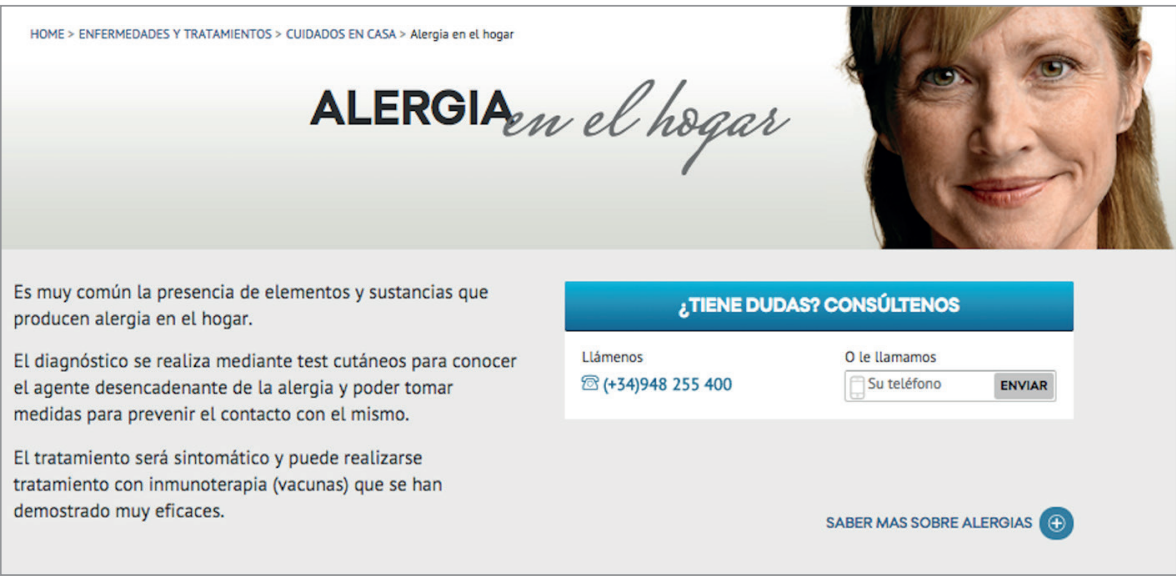

CUN corporate website
Indeed, in both cases, the commitment to image and/or video content was shown. It highlighted CUN's innovative commitment to careful computer graphics that summarize and explain health information at a glance. The availability of an area for multimedia communication explains the innovation and care in the use of this type of content. In contrast, $H S J D$, with fewer resources and without a specialized area within the department, makes too much use of photography or image to illustrate most of its publications. 
The Facebook/Twitter contrast shows, first, that more activity is not synonymous to more interaction with audiences. Although CUN has more activity in both networks, HSJD stands out for the participation of its content in Facebook and CUN on Twitter. The communicty of the Catalan hospital on Facebook is superior to that of Navarre, which may be a conditioning. But its number of followers on Twitter is also higher and yet the participation of its audiences is lower. This may be because Facebook is employed by HSJD as a community channel where parents find articles of interest about their children's health. However, CUN's corporate strategy on Facebook reveals a more diluted success. This could be due to several factors: 1) It is a general hospital, which gives rise to content of various types and does not clearly limit the characteristics of the public that receives the messages (as opposed to a specialized hospital, with a profile of publics that is much more concrete and very clear from the department of communication); 2) The prioritization of corporate strategy, which on Facebook can attract a conquered public, but may have less pull for potential audiences, who a priori do not know the institution and will be less involved in opening a new venue; 3 ) The profile of a private service organization, which limits the potential reach of its audiences.

On Twitter, however, the opposite situation occurs. It works better at the service of a corporate strategy than an informational/ educational one. Twitter helps and promotes relationships and networking, as highlighted by Hart et al. (2017). Because CUN is a university hospital, there is a solid network woven between the University's own institutions, which can initially serve as a support for the retransmission of the generated content (Center for Applied Medical Research, CIMA; Faculties of Medicine and Nursing of the University, University of Navarra and CUN, mainly). To this must be added the new relationships that are created with other institutions. The fact that both hospitals are linked to the University favors a daily relational component with other prestigious entities related to their interests and activity.

Therefore, Facebook may be the most appropriate platform for outreach strategies while Twitter may be best for corporate relational strategies.

As both networks are general-interest, scientific content is less strategically present and receives less attention from non-specialized audiences.

The interaction and participation of the public occurs in three types of issues (in order of impact):

1) Health issues of general concern, sensitive, and topical (cancer, childhood cancer, Alzheimer's);

2) recognized personal and professional projects, as well as initiatives for struggle or sensitization (medical trajectories or projects in favor of a person, for instance);

3) important corporate novelties that affect the organization and encourage public involvement.

The continuity of this line of research is recommended to corroborate our finding that Facebook is best for strategies of health disclosure and Twitter for corporate strategies, as well as the contrast between public and private profiles or between specialist and generalist hospitals. The main limitation of the work is that we have analyzed only the main platforms and social networks of two hospitals. In addition, they are two reference hospitals (in their activity in general and in their online activity in particular) so two advantageous situations (in terms of activity level and available resources) are evaluated in relation to most hospitals in Spain.

The scope of 2.0 generates a conversational potential that hospital institutions must take advantage of to become a source of reference information for their audiences. The greatest challenge for scholars is to learn how to institutionalize strategic public relations as an ongoing accepted practice in most organizations (Grunig, 2010). The vector of health communication can serve with this double objective: to maintain or improve relations with the public while educating about health.

\section{References}

Arencibia-Jiménez, Mercedes; Aibar-Remón, Carlos (2007). "Páginas web de hospitales. Realidad virtual o... ¿̇son realmente un medio útil para la difusión de información para sus usuarios?". Revista de calidad asistencial, v. 22, n. 3, pp. 118-127.

https://doi.org/10.1016/S1134-282X(07)71206-X

Bermúdez-Tamayo, Clara; Alba-Ruiz, Rubén; Jiménez-Pernett, Jaime; García-Gutiérrez, José-Francisco; Traver-Salcedo, Vicente; Yubraham-Sánchez, David (2013). "Use of social media by Spanish hospitals: Perceptions, difficulties, and success factors". Telemedicine and e-health, v. 19, n. 2, pp. 137-145.

https://doi.org/10.1089/tmj.2012.0066

Briones, Rowena; Kuch, Beth; Liu, Brooke-Fisher; Jin, Yan (2011). "Keeping up with the digital age: How the American Red Cross uses social media to build relationships". Public relations review, v. 37, n. 1, pp. 37-43.

https://doi.org/10.1016/j.pubrev.2010.12.006

Calvo-Calvo, Manuel-Ángel (2014). “Calidad y características de los sitios web de los hospitales españoles de gran tamaño". Revista española de documentación científica, v. 37, n. 1, pp. 1-19.

https://doi.org/10.3989/redc.2014.1.1049

Costa-Sánchez, Carmen; Túñez-López, Miguel; Videla-Rodríguez, José-Juan (2016). “Hospitales españoles en la web social. Gestión de Facebook y Twitter por el Hospital Sant Joan de Dèu (Barcelona)". Revista latina de comunicación social, n. 71, pp. 1108-1130.

https://doi.org/10.4185/RLCS-2016-1137

Díaz-Cuenca, Antonia-María (2007). "Análisis de la calidad de las páginas web en los hospitales españoles". Enfermería global, v. 6, n. 1, pp. 1-13.

http://revistas.um.es/eglobal/article/view/224

Farabough, Lauren-Alesha (2013). Using Facebook as a public relations tactic: A look at how hospitals are engaging with fans. Doctoral dissertation. University of Arkansas at Little Rock.

Gabarrón, Elia; Fernández-Luque, Luis (2012). “eSalud y ví- 
deos online para la promoción de la salud". Gaceta sanitaria, v. 26, n. 3, pp. 197-200.

https://doi.org/10.1016/j.gaceta.2012.03.004

Griffis, Heather; Kilaru, Austin; Werner, Rachel; Asch, David; Hershey, John; Hill, Shawndra; Ha, Yonhee; Sellers, Allison; Mahoney, Kevin; Merchant, Raina (2014). "Use of social media across US hospitals: Descriptive analysis of adoption and utilization". Journal of medical internet research, v. 16, n. 11, pp. 264.

https://doi.org/10.2196/jmir.3758

Grunig, James E. (2006). “Furnishing the edifice: Ongoing research on public relations as a strategic management function". Journal of public relations research, v. 18, n. 2, pp. 151-176.

https://doi.org/10.1207/s1532754xjprr1802_5

Hart, Mark; Stetten, Nichole E.; Islam, Sabrina; Pizarro, Katherine (2017). "Twitter and public health (Part 1): How individual public health professionals use Twitter for professional development". JMIR Public health and surveillance, $v$. 3, n. 3, e60.

https://doi.org/10.2196/publichealth.6795

Hu, Yifeng; Sundar, Shyam (2010). "Effects of online health sources on credibility and behavioral intentions". Communication research, v. 37, n. 1, pp. 105-132.

https://doi.org/10.1177/0093650209351512

Huerta, Timothy; Hefner, Jennifer; Ford, Eric; McAlearney, Anne-Scheck; Menachemi, Nir (2014). "Hospital website rankings in the United States: Expanding benchmarks and standards for effective consumer engagement". Journal of medical internet research, v. 16, n. 2, e64.

https://doi.org/10.2196/jmir.3054

IAB Spain (2016). Estudio anual de redes sociales. https://www.slideshare.net/elogia/estudio-redes-sociales-2016

King, Melanie (2014). Corporate blogging and microblogging: An analysis of dialogue, interactivity and engagement in organisation-public communication through social media. Doctoral dissertation. Sidney: University of Technology, Sydney (UTS).

https://opus.lib.uts.edu.au/bitstream/10453/35948/2/02whole. $p d f$

Kordzadeh, Nima; Young, Diana (2015). “Understanding how hospitals use social media: An exploratory study of Facebook posts". In: Americas conference on information systems. Virtual communities and collaboration. Association for Information Systems.

http://aisel.aisnet.org/amcis2015/VirtualComm/ GeneralPresentations/4

Leung, Ricky (2014). "Increasing dynamic capabilities of health organizations with social media". In: Olivas-Luján, Miguel; Bondarouk, Tanya (eds.). Social media in strategic management, pp. 129-142. ISBN: 9781781908983

Lim, Weng-Marc (2016). "Social media in medical and health care: Opportunities and challenges". Marketing intelligence \& planning, v. 34, n. 7, pp. 964-976.

https://doi.org/10.1108/MIP-06-2015-0120
Martínez-Millana, Antonio; Fernández-Llatas, Carlos; Basagoiti-Bilbao, Ignacio; Traver-Salcedo, Manuel; Traver-Salcedo, Vicente (2017). "Evaluating the social media performance of hospitals in Spain: A longitudinal and comparative study". Journal of medical internet research, v. 19, n. 5, e181. https://doi.org/10.2196/jmir.6763

McCaughey, Deirdre; Baumgardner, Catherine; Gaudes, Andrew; LaRochelle, Dominique; Wu, Kaila-Jyaxin; Raichura, Tejal (2014). "Best practices in social media: Utilizing a value matrix to assess social media's impact on health care". Social science computer review, v. 32, n. 5, pp. 575-589. https://doi.org/10.1177/0894439314525332

Medina-Aguerrebere, Pablo; Buil-Gazol, Pilar; Heath, Robert (2015). "Brand dissemination in Canadian hospitals through Facebook". The International journal of communication and health, v. 7, pp. 27-39.

http://communicationandhealth.ro/upload/number7/ PABLO-MEDINA.pdf

Moorhead, Ann; Hazlett, Diane; Harrison, Laura; Carroll, Jennifer; Irwin, Anthea; Hoving, Ciska (2013). "A new dimension of health care: systematic review of the uses, benefits, and limitations of social media for health communication". Journal of medical internet research, v. 15, n. 4, e85. https://doi.org/10.2196/jmir.1933

Rando-Cueto, Dolores; Paniagua-Rojano, Francisco-Javier; De-las-Heras-Pedrosa, Carlos (2016). "Factores influyentes en el éxito de la comunicación hospitalaria vía redes sociales". Revista latina de comunicación social, v. 71, pp. 11701186.

https://doi.org/10.4185/RLCS-2016-1140

Richter, Jason; Muhlestein, David; Wilks, Chrisanne (2014). "Social media: How hospitals use it, and opportunities for future use". Journal of healthcare management, v. 59, n. 6, pp. 447-461.

Sale, Joanna; Lohfeld, Lynne; Brazil, Kevin (2002). "Revisiting the quantitative-qualitative debate: Implications for mixed-methods research". Quality and quantity, v. 36, n. 1, pp. 43-53.

https://doi.org/10.1023/A:1014301607592

Sarasohn-Kahn, Jane (2008). The wisdom of patients: Health care meets online social media. California HealthCare Foundation.

http://www.chcf.org/publications/2008/04/the-wisdom-ofpatients-health-care-meets-online-social-media

Saxton, Gregory; Waters, Richard (2014). "What do stakeholders like on Facebook? Examining public reactions to nonprofit organizations' informational, promotional, and community-building messages". Journal of public relations research, v. 26, n. 3, pp. 280-299.

https://doi.org/10.1080/1062726X.2014.908721

Thackeray, Rosemary; Neiger, Brad; Smith, Amanda; Van-Wagenen, Sarah (2012). "Adoption and use of social media among public health departments". BMC public health, v. 12, n. 1, pp. 242.

https://doi.org/10.1186/1471-2458-12-242 
Timian Alex; Rupcic, Sonia; Kachnowski, Stan; Luisi, Paloma (2013). "Do patients 'like' good care? Measuring hospital quality via Facebook". American journal of medical quality, v. 28, n. 5, pp. 374-382.

https://doi.org/10.1177/1062860612474839

Van-de-Belt, Tom; Berben, Sivera; Samsom, Melvin; Engelen, Lucien; Schoonhoven, Lisette (2012). "Use of social media by Western European hospitals: Longitudinal study". Journal of medical internet research, v. 14, n. 3, e61.

https://doi.org/10.2196/jmir.1992

Vanzetta, Marina; Vellone, Ercole; Dal-Molin, Alberto; Rocco, Gennaro; De-Marinis, Maria-Grazia; Rosaria, Alvaro (2014). "Communication with the public in the health-care system: A descriptive study of the use of social media in local health authorities and public hospitals in Italy". Annali dell'Istituto Superiore di Sanità, v. 50, n. 2, pp. 163-170. https://doi.org/10.4415/ANN_14_02_10

Wong, Charlene; Ostapovich, Gabrielle; Kramer-Golinkoff, Emily; Griffis, Heather; Asch, David; Merchant, Raina (2016). "How US children's hospitals use social media: A mixed methods study". Healthcare, v. 4, n. 1, pp. 15-21. https://doi.org/10.1016/j.hjdsi.2015.12.004

Xifra, Jordi; Grau, Francesc (2010). "Nanoblogging PR: The discourse on public relations in Twitter". Public relations review, v. 36, n. 2, pp. 171-174.

https://doi.org/10.1016/j.pubrev.2010.02.005

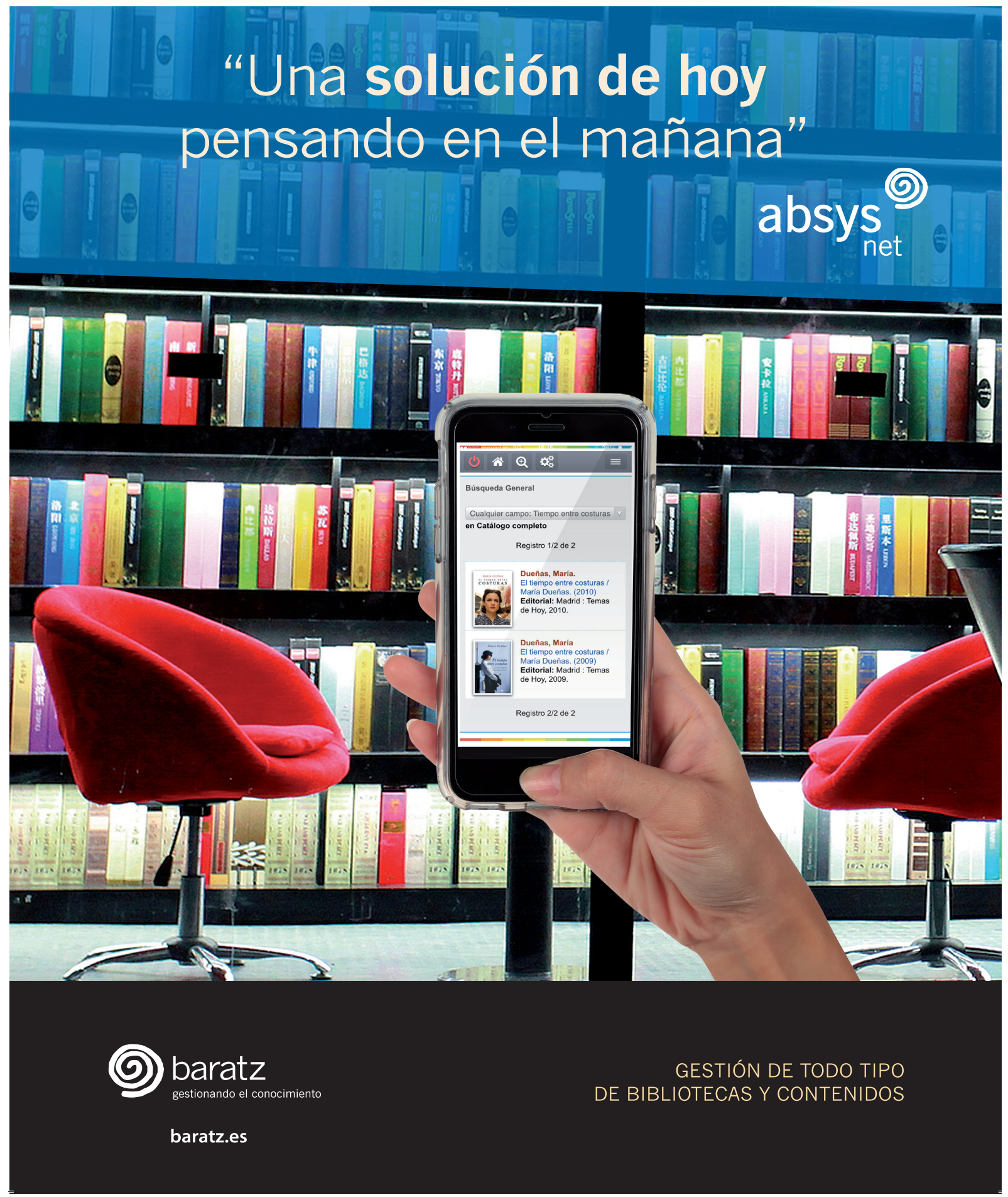

